\title{
小規模遊休農地の活用に向けたエネルギー作物としての ヤナギ生産の基礎的研究
}

\author{
一経済的視点からの考察— \\ Basic Study of Willow Production as an Energy Coppice and its Issue toward Use of Small-scale Idle Farmlands: \\ Discussion from an Economical Point of View \\ 森本英嗣* 佐藤 茂 ${ }^{* *}$ 石澤公明 $* *$ 新井 健 ${ }^{* * * *}$ \\ Hidetsugu MORIMOTO*, Shigeru SATOH**, Kimiharu ISHIZAWA*** and Takeshi ARAI**** \\ ( *長野大学環境ツーリズム学部 **龍谷大学農学部 ***宮城教育大学教育学部 ****東京理科大学理工学部) \\ (*Faculty of Tourism and Environmental Studies, Nagano University, **Faculty of Agriculture, Ryukoku University, \\ *** Faculty of Education, Miyagi University of Education and ****Faculty of Science and Technology, Tokyo University of Science)
}

I はじめに

今日，我が国においてエネルギーの地産地消が注目さ れている。エネルギーコストの上昇と温室効果ガスの排 出量の問題解決に向かうべく, 第 4 次エネルギー基本計 画が閣議決定 (2014 年 4 月), さらには農山漁村再生可 能エネルギー法（2014 年 5 月 1 日施行）が成立し, 農 山漁村地域では今後, 各地域の「土地利用を勘案した調 和のとれた再生可能エネルギー」1)の導入が求められる ようになる。

一方，近年では遊休農地増加の問題は農山村地域のみ ならず都市近郊にも及んでいる。近年，遊休農地の活用 方法として恒久転用による太陽光発電施設の整備が進 み，固定価格買取制度による新たな収入源として見直さ れている。しかし，農地の不可逆性を鑑みれば，本来極 めて慎重を期すものであり, 判断を誤れば農地の生産能 力を損失し前述の「調和のとれた」土地利用からほど遠 くなってしまう恐れがある。

そこで，本報は農地の生産能力保持を前提とした再生 可能エネルギー生産に着目し, 次世代バイオマスのひと つとして注目されているヤナギの生産費について報告す る。ヤナギのバイオマス利用に関する研究は, 国外と りわけ欧米諸国での研究報告が多い（例えば, Sara et $a l .{ }^{2)}$, Beyhan et al. $\left.{ }^{3)}\right)$ 。その生産規模は数へクタール に及び，生産されたヤナギはエタノール（液体燃料）や 熱の原料・資源として利用されている。一方，国内にお けるヤナギに関する研究は, 北海道開発局 ${ }^{4)}$ や森林総合 研究所 ${ }^{5)}$ ならびに佐藤ら ${ }^{6}$ や Satoh et al. ${ }^{7)}$ による栽培 研究に留まり, 前 2 編はいずれも面積 1 ha 以上の実績 報告である。後 2 編は遊休農地によく見られるような小
規模農地での研究であり, 生産性の高い品種（エゾノキ ヌヤナギ:KKD）ならびに性質（化学成分組成, 発熱量) の特定のみに留まっている。これら既存研究は生産費に は着目して㧍らず, Rosenqvist and Dawson ${ }^{8)}$ による経 済性評価はあるが, 小規模（1 ha 未満）農地での生産 費について言及した報告は現時点で確認されていない。 本報は, 小規模農地での試験栽培を通して生産費を試算 し，国内に打けるヤナギ生産に関する先駆的情報を提示 する。

IIIエネギー作物としてのヤナギ生産

\section{1 ヤナギの性質}

ヤナギはヤナギ科に属し, 早生広葉樹の木本植物で ある。萌芽再生能力が高く約 20 年にわたって $1 \sim 2$ 年 周期での収穫が可能である。先進国であるスウェーデ ンでは既に商業的な生産が 1980 年代から行われ，2009 年時点で約 14,000 ha もの土地で栽培されている。 22 年 間の生産期間で年平均生産量は 0.3 (無施肥区) $\sim 0.79$ (施肥区) dry-t/10 a と報告されている ${ }^{2)} 。 一$ 方, 国 内の報告では, 先述の佐藤ら（2009）およびSatoh $e t$ al.（2012）により，エゾノキヌヤナギ（KKD）の生産 量が最も多く, 2 年間 ( 2 生育期間) で $26.8 \mathrm{dry}-\mathrm{t} / \mathrm{ha}$ と 報告され, 温暖な日本の方が単位面積当たりの生産量が 高いとされる。

\section{2 生産方法}

遊休農地を活用したヤナギの生産は 6 つの工程（ほ場 の整備, 整地, 植え付け, 維持管理, 収穫, 農地復旧) に区分される（図 1）。 
表 1 試験ほ場の気象条件ならびに栽培条件

Table 1 Meteorological and planting condition at field sites

\begin{tabular}{|c|c|c|c|c|c|c|c|c|}
\hline & \multirow{2}{*}{$\begin{array}{l}\text { 気温 } \\
\left({ }^{\circ} \mathrm{C}\right) \\
\end{array}$} & \multirow{2}{*}{$\begin{array}{l}\text { 降水量 } \\
\text { (m) }\end{array}$} & \multicolumn{2}{|c|}{ 相対湿度（\%） } & \multirow{2}{*}{$\begin{array}{c}\text { 面積 } \\
\text { (a) }\end{array}$} & \multirow{2}{*}{ 栽培期間 } & \multirow{2}{*}{ 植栽本数 } & \multirow{2}{*}{ 植栽前の利用状況 } \\
\hline & & & 平均 & 最小 & & & & \\
\hline 茨城県土浦市（T 区） & 14.5 & 1,199 & 74.8 & 26.4 & 50.0 & 2011. $3-2012.12$ & 4,500 & 園芸花木（観賞用ヤナギ）栽培 \\
\hline 宮城県川崎町 (K 区) & 12.5 & 1,249 & 71.3 & 28.7 & 46.8 & 2012. $4-2013.12$ & 3,516 & 不耕作，堆肥（搾乳牛排せつ物）仮置き場 \\
\hline
\end{tabular}

気象条件（気温，降水量，相対湿度）はいずれも気象庁 ${ }^{9)}$ 10) を参照し，1984 年 1 月〜 2013 年 12 月までの平年值である。

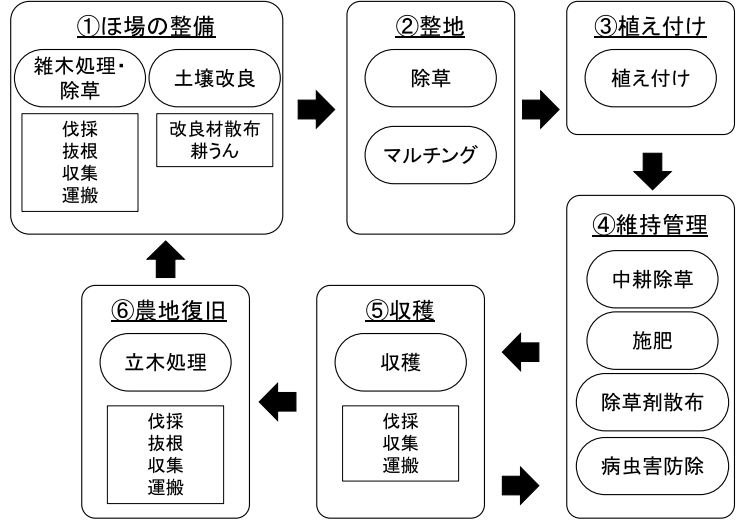

1 年目 : 準備期 (1) (4)

2 年目以降 : 収穫期(4)・(5) と非収穫期(4)を交互にむかえる 20 年目：最終期(4) - (5) - (6)

図 1 ヤナギ生産工程フロー図

Fig. 1 Flow chart of willow production process

遊休農地を活用する場合，状態にもよるが雑木および 雑草の除去が必要となる。本報におけるほ場の整備工程 では，雑草の除去（刈り払いと運搬）とした。整地工程 では，トラクターによる耕うん・整地に加え，生産過程 での除草作業の効率化を考慮してマルチングを実施し た。維持管理工程では，除草，施肥等を行い，即間の除 草作業は，トラクターならびにエンジン付き刈り払い機 （以下，刚り払い機）による中耕除草とした。収穫の伐 採作業はチェーンソーならびに刈り払い機を使用し，人 力作業によりヤナギを収集し，トラックに積み込んだ。

ヤナギ生産は 20 年を 1 サイクルとして, 1 年おきに 収穫を実施する。生産開始年（1 年目）は, ほ場の整備, 整地，植え付け，維持管理の工程を実施する準備期，2 年目は維持管理と収穫の工程を実施する収穫期， 3 年目 は維持管理工程のみの非収穫期である。 4 年目以降は 2 年目の工程と 3 年目の工程の繰り返しとなる。そして最 終年（20 年目, 最終期) は, 収穫後に農地復旧工程を 実施し，再び準備期に戻る。

\section{III 研究の方法}

\section{1 試験ほ場ならびに生産方法}

栽培するヤナギはエゾノキヌヤナギ（KKD）とし， 栽培は茨城県土浦市（T区), 宮城県川崎町（K区）の
$\mathrm{T}$ 区（茨城県土浦市）
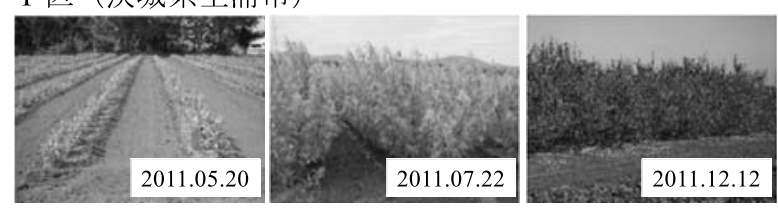

K区（宮城県川崎町）
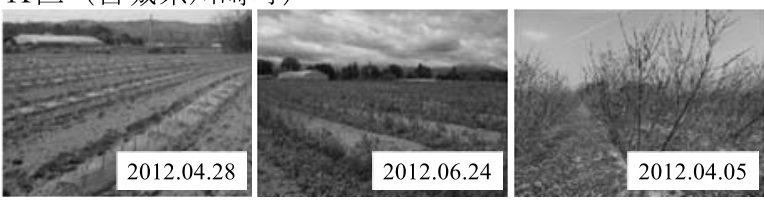

図 2 栽培の様子

Fig. 2 Appearance of willow fields

表 2 植栽方法（㽞間間隔，植栽間隔）

Table 2 Planting Method (furrow and plant interval)

\begin{tabular}{c|c|c|c|c}
\hline \hline $\begin{array}{c}\text { 単位 } \\
(\mathrm{cm})\end{array}$ & $\begin{array}{c}\text { 嘼間 } \\
(\mathrm{b})\end{array}$ & $\begin{array}{c}\text { 䒽幅 } \\
(\mathrm{B})\end{array}$ & $\begin{array}{c}\text { 株間 } \\
(\mathrm{L})\end{array}$ & 概略図 \\
\hline $\mathrm{T}$ 区 & 120 & 70 & 50 &
\end{tabular}

ほ場で実施した。面積はそれぞれ $50.0 \mathrm{a}, 46.8$ a とした。 ほ場は共に温暖湿潤気候（Cfa：ケッペンの気候区分） に属し，それぞれの気象条件，栽培期間等は表 1 に示す。

$\mathrm{T}$ 区では 2011 年 3 月〜同年 12 月を準備期， 2012 年 1 月〜同年 12 月を収穫期とした。 $\mathrm{K}$ 区では 2012 年 4 月〜 2012 年 12 月を準備期, 2013 年 1 月〜同年 12 月を収穫 期とした。 $\mathrm{T}$ 区は借地期間が限定されていたため, 栽培 期間を 2 年とし, 収穫が終了した時点で農地の復旧を実 施した。一方，K区は収穫期が終了してもそのまま栽培 を継続している。ここで，K区はより粗放的（省力的） な栽培方法の試験区として位置づけ，作業と物財の投入 量を把握し，単価は $\mathrm{T}$ 区の水準によって試算すること とする。

植栽方法は両区で異なる。ヤナギは挿し木による繁殖 が可能であり，生育期間 3〜 4 年の幼木（30 cm）をそ れぞれ表 2 のように植え付けた。栽培管理については, T 区では，園芸花木（観賞用ヤナギ）を生産している造 園業者に作業を委託し, 従来通りの栽培方法を実施して もらった。一方, K 区では, 農地所有者（農家）に極力 省力的な作業を実施してもらった。 
表 3 試算に用いた単価の一覧

Table 3 Expenditure unit price for estimation

\begin{tabular}{|c|c|}
\hline 作業委託費 & 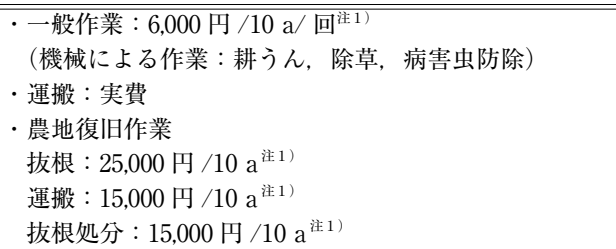 \\
\hline 作業労賃 & $\begin{array}{l}\text { ·労賃 } \\
\text { 手作業 : } 1,125 \text { 円 / 時間 }(9,000 \text { 円 / 人工 }) \text { 注1 } 1) \\
\text { ·技術料 } \\
\text { マルチング設置 }: 1,500 \text { 円 } / 200 \mathrm{~m}^{\text {iæ} 11)} \\
\text { チェーンソー使用 }: 12,900 \text { 円 / 人工 }{ }^{\text {ia } 2)}\end{array}$ \\
\hline 物財費 & 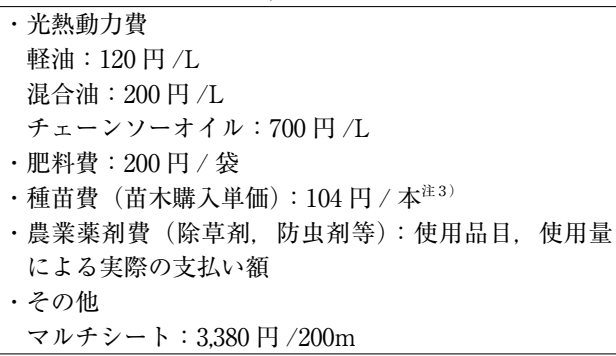 \\
\hline 借地料 & 10,000 円 $/ 10 \mathrm{a}$ \\
\hline $\begin{array}{l}\text { 主: 1) 土 } \\
\text { 2) 平 } \\
\text { 3) 兵) }\end{array}$ & $\begin{array}{l}\text { 基準による } \\
16 \text { 年林業労働者職種別貨金調查 }{ }^{11} \text { 参照 } \\
\text { 目林業種苗共同組合 }{ }^{12} \text { 参照 }\end{array}$ \\
\hline
\end{tabular}

\section{2 生産費の算出}

（1）費用算出

本報では，生産における経費は作業委託費，作業労賃， 物財費，借地料の費目に限定し（表 3)，図 1 に示す（ほ 場の整備から農地復旧までの）範囲とした。労働費を作 業委託費と作業労賃に分けた理由は，作業委託費の割合 が大きいためである。

準備期の費用は各工程（ほ場の整備, 整地, 植え付け, 維持管理）の費用，収穫期は，維持管理ならびに収穫工 程での費用, 非収穫期は維持管理費のみとなる。但し, 各期とも借地料を含む。

非収穫期は，準備期と同様の維持管理が実施されると 考えた。さらに, 最終期は, 収穫後に農地復旧作業を実 施するものとする (廃棄費用)。最後に，今回の生産ほ 場で使用した苗木は無償提供であったため, 購入費用は 発生なかったが，一連の経費を算出するため，購入価格 を 104 円/本 ${ }^{(1)}$ として積算した。

ヤナギ生産に要した費用の程度を測るため慣行農業と 比較し，その差を確認する。その際，借地料を除いた費用 を用いて比較するが, 本稿ではこれを生産費と定義する。

\section{3 生産工程の省力検討}

K 区での作業投入量ならびに生産量から，ヤナギ生産 の省力化を検討する。費用試算の際，K区での作業に対 して作業者に支払った費用では，労賃と燃料費が分かれ
表 $4 \mathrm{~T}$ 区での投入量ならびに費用

Table 4 Workloads and costs during the production at site $\mathrm{T}$

\begin{tabular}{|c|c|c|c|c|}
\hline 生产工程 & 内容 & 費目注1) & 投入量 & $\begin{array}{c}\begin{array}{c}\text { 費用 } \\
(\text { 円 } / 10 \mathrm{a})\end{array} \\
\end{array}$ \\
\hline (1)ほ場の整備 & 除草（処分含む） & 委託 & 1 回 & 6,000 \\
\hline $\begin{array}{l}\text { (2)整地 } \\
\text { 耕うん } \\
\text { マルチング }\end{array}$ & $\begin{array}{l}\text { トラクター } \\
\text { 設置作業 } \\
\text { 人カ作業 } \\
\text { マルチシート }\end{array}$ & $\begin{array}{l}\text { 委託 } \\
\text { 労賃 } \\
\text { 労賃 }\end{array}$ & $\begin{array}{c}1 \text { 回 } \\
1,800 \mathrm{~m}^{\text {注 } 2)} \\
4 \text { 人工 } \\
1,800 \mathrm{~m} \\
\end{array}$ & $\begin{array}{l}6,000 \\
2,565 \\
7,200 \\
6,084 \\
\end{array}$ \\
\hline (3)植え付け & $\begin{array}{l}\text { 人力作業 } \\
\text { 苗木 }\end{array}$ & $\begin{array}{l}\text { 労賃 } \\
\text { 物 }\end{array}$ & $\begin{array}{c}5 \text { 人工 } \\
4,500 \text { 本 }\end{array}$ & $\begin{array}{r}9,000 \\
93,600 \\
\end{array}$ \\
\hline $\begin{array}{l}\text { (4)維持管理 } \\
\text { 除草 }\end{array}$ & & & & \\
\hline 準備期 & $\begin{array}{l}\text { トラクター } \\
\text { (軽油) } \\
\text { 人カ作業 } \\
\text { トラクター } \\
\text { (軽油) }\end{array}$ & $\begin{array}{l}\text { 委託 } \\
\text { 物財 } \\
\text { 労賃 } \\
\text { 委託 } \\
\text { 物財 }\end{array}$ & $\begin{array}{c}13.5 \text { 回 } \\
280 \mathrm{~L} \\
121.5 \text { 時間 } \\
2.5 \text { 回 } \\
100 \mathrm{~L}\end{array}$ & $\begin{array}{r}81,000 \\
6,720 \\
27,338 \\
15,000 \\
2,400\end{array}$ \\
\hline 施肥 & & & & \\
\hline 準備期 & $\begin{array}{l}\text { 人力作業 } \\
\text { (肥料代) }\end{array}$ & $\begin{array}{l}\text { 労賃 } \\
\text { 物財 }\end{array}$ & $\begin{array}{l}2 \text { 人工 } \\
70 \text { 袋 }\end{array}$ & $\begin{array}{l}3,600 \\
2,800\end{array}$ \\
\hline $\begin{array}{r}\text { 収穫期 } \\
\text { 除草剂散布 }\end{array}$ & 無施肥 & & - & 0 \\
\hline 準備期 & $\begin{array}{l}\text { 動力散布機 } \\
\text { (混合油) } \\
\text { (薬剤費) }\end{array}$ & $\begin{array}{l}\text { 労賃 } \\
\text { 物財 } \\
\text { 物財 }\end{array}$ & $\begin{array}{c}43.5 \text { 時間 } \\
78 \mathrm{~L} \\
-\end{array}$ & $\begin{array}{r}9,788 \\
3,120 \\
10,489\end{array}$ \\
\hline 収穫期 & $\begin{array}{l}\text { 手動式背負噴霧器 } \\
\text { (薬荗費) }\end{array}$ & $\begin{array}{l}\text { 労賃 } \\
\text { 物財 }\end{array}$ & $\begin{array}{c}26 \text { 時間 } \\
-\end{array}$ & $\begin{array}{l}5,850 \\
8,762\end{array}$ \\
\hline $\begin{array}{c}\text { 病害虫防除 } \\
\text { 準備期 }\end{array}$ & スピードスプレイヤー & 委託 & 3 回 & 3,600 \\
\hline & $\begin{array}{l}\text { (軽油) } \\
\text { (薬剤費) }\end{array}$ & $\begin{array}{l}\text { 物財 } \\
\text { 物財 }\end{array}$ & $\begin{array}{c}60 \mathrm{~L} \\
-\end{array}$ & $\begin{array}{l}1,440 \\
2,686\end{array}$ \\
\hline 収穫期 & $\begin{array}{l}\text { スピードスプレイヤー } \\
\text { (軽油) } \\
\text { (薬剤費) }\end{array}$ & $\begin{array}{l}\text { 委託 } \\
\text { 物財 } \\
\text { 物財 }\end{array}$ & $\begin{array}{c}2 \text { 回 } \\
40 \mathrm{~L} \\
-\end{array}$ & $\begin{array}{r}2,400 \\
960 \\
2,954\end{array}$ \\
\hline (5)收穫 & & & & \\
\hline 伐採 & $\begin{array}{l}\text { チェーンソー伐採 } \\
\text { 伐採補助 } \\
\text { (混合油) } \\
\text { (チェーンソーオイル) }\end{array}$ & $\begin{array}{l}\text { 労賃 } \\
\text { 労賃 } \\
\text { 物財 } \\
\text { 物財 }\end{array}$ & $\begin{array}{c}5 \text { 人工 } \\
5 \text { 人工 } \\
60 \mathrm{~L} \\
4 \mathrm{~L}\end{array}$ & $\begin{array}{r}12,900 \\
9,000 \\
2,400 \\
560\end{array}$ \\
\hline $\begin{array}{l}\text { 収集 } \\
\text { 運搬 }\end{array}$ & $\begin{array}{l}\text { 人力作業 } \\
\text { 運搬 }\end{array}$ & $\begin{array}{l}\text { 労賃 } \\
\text { 委託 }\end{array}$ & $\begin{array}{c}12.5 \text { 時間 } \\
-\end{array}$ & $\begin{array}{r}2,813 \\
37,840 \\
\end{array}$ \\
\hline $\begin{array}{l}\text { (6)農地復旧 } \\
\text { 抜根 } \\
\text { 運搬 } \\
\text { 処分 }\end{array}$ & $\begin{array}{l}\text { 抜根・土払い } \\
\text { 運搬・積み込み } \\
\text { 根材処分 }(3.0 \mathrm{t})\end{array}$ & $\begin{array}{l}\text { 委託 } \\
\text { 委託 } \\
\text { 委託 }\end{array}$ & $\begin{array}{l}- \\
- \\
-\end{array}$ & $\begin{array}{l}25,000 \\
15,000 \\
15,000\end{array}$ \\
\hline
\end{tabular}

注：1）委託は作業委託費，物財は物財費を意味する。

$2 ）$ 実際の設置延長は $1,710 \mathrm{~m} （ \fallingdotseq 95 \mathrm{~m} /$ 列 $\times 18$ 列 $)$ である。

ていなかった点, 支払い基準が $\mathrm{T}$ 区と異なる点注2) から K区での支払金額の言及は避け，実際に掛かった作業投 入量 (人工注3), 時間)の久を整理し, T 区の支払い単価 (表 3）を参考に K 区の経費を算出した。本来ならば，各ほ 場にて対照区を設けて生産工程の省力化を検証する必要 があるが，作業委託費用支払いの都合上，同一区画内で の作業分割（面積割り）が困難であったため， T 区は既 存のヤナギ生産方法, K 区は省力生産方法という位置付 けで検証を行う。また, 生産管理主体の違い（年齢, 農 業形態による使用機械の種類）によって作業効率性や生 産量の差異が生じる可能性があるが，その点については $\mathrm{V}$ 章 2 節で述べる。 

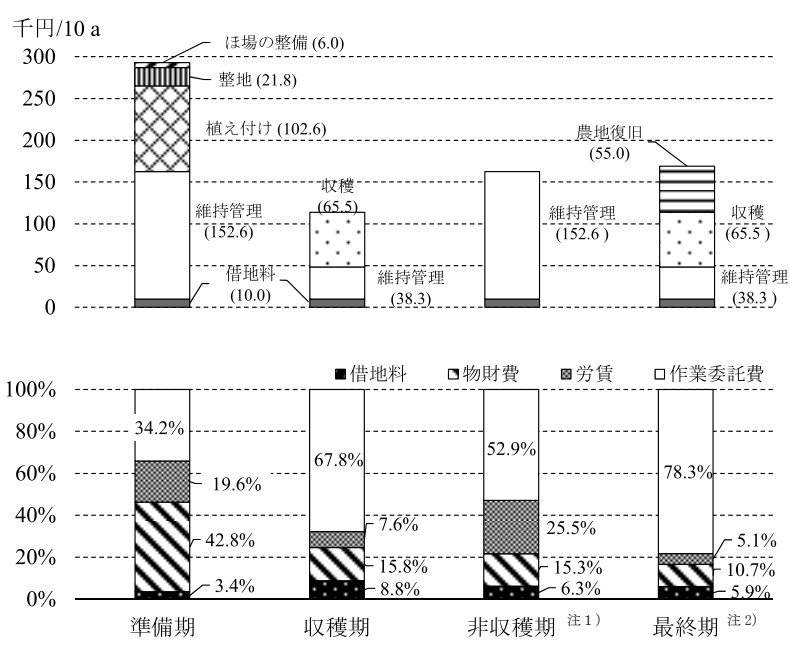

注：1）維持管理費は準備期の費用を代用

2）維持管理費，収穫費は収穫期の費用を代用

図 3 T 区における各期のヤナギ経費 （上段：工程別積算，下段：費目別割合）

Fig. 3 Cost of each production season at site $\mathrm{T}$ (top: integrated cost by process, bottom: ratio of cost)

\section{IV 生産における作業投入量と費用}

\section{T 区での期別費用}

$\mathrm{T}$ 区における第 $1 ， 2$ 期の作業投入量と費用別の結果 を表 4 に，各期別の単位面積（10 a 当たり）の積算費 用を図 3 に示す。

準備期の費用は約 30 万円 $/ 10$ a となり (図 3 上段), その多くが植え付けと維持管理の合計費用 $(87.1 \%)$ と なった。特に，維持管理費用が半分以上（52.1\%）の費 用を要した。T区では，除草作業が 13.5 回（ロータリ 一耕)，121.5 時間（人力作業；人工に換算すると 15.2 人工）と月 1 回程度の頻度で行われていたこと，そのほ とんどが作業委託費であったことから維持管理費用の中 でも除草作業費用が圧倒的に多かった。次いで除草剤散 布が $8.5 \%$ ，病害虫防除が $5.1 \%$ の割合を占めた。ヤナギ の成長速度は速いうえにある程度の丈になると畧間は遮 光率が高くなり, 雑草の繁茂は比較的抑制される。今回 T 区においては，観賞用ヤナギの生産方法に準じた除草 作業ということもあり，最大限の作業投入量であったと 考えられ，これ以上の除草作業はないといえる。

収穫期に入ると維持管理費用が大幅に減少し，全体の 経費は準備期の半分以下になった。維持管理費用も準備 期に比べて 4 分の 1 程度に減り, 成長に伴う除草作業の 軽減によるものと考えられる。もちろん収穫費用が発生 するが，最も低い時期であった。

非収穫期は，準備期での維持管理工程と同様の作業投 入量が予想される。既述のとおりヤナギは成長するに従
表 5 K 区での投入量ならびに費用

Table 5 Workloads and cost during the production at site $\mathrm{K}$

\begin{tabular}{|c|c|c|c|c|}
\hline 生产工程 & 内容 & 費目注1) & 投入量 & $\begin{array}{c}\text { 費用 } \\
\text { (円 } / 10 \mathrm{a})\end{array}$ \\
\hline (1)ほ場の整備 & $\begin{array}{l}\text { 未実施（整地と } \\
\text { 同時実施） }\end{array}$ & & - & \\
\hline \multicolumn{5}{|l|}{ (2)整地 } \\
\hline 耕うん & トラクター（耕 & 委託 & 1 回 & 6,000 \\
\hline マルチング & うんと同時) & 物材 & $1,800 \mathrm{~m}^{\text {注 } 2)}$ & 6,500 \\
\hline \multirow[t]{2}{*}{ (3)植え付け } & 人力作業 & 労賃 & 6 人工 & 11,538 \\
\hline & 苗木 & 物材 & 3,516 本 & 78,104 \\
\hline \multicolumn{5}{|l|}{$\begin{array}{c}\text { (4)維持管理 } \\
\text { 除草 }\end{array}$} \\
\hline \multirow[t]{3}{*}{ 準備期 } & トラクター & 委託 & 4 回 & 24,000 \\
\hline & 刈り払い機 & 労賃 & 16 時間 & 3,846 \\
\hline & （混合油） & 物材 & $4.8 \mathrm{~L}^{\text {ì } 3)}$ & 205 \\
\hline \multirow[t]{3}{*}{ 収穫期 } & トラクター & 委託 & 2 回 & 12,000 \\
\hline & 刈り払い機 & 労賃 & 16 時間 & 3,846 \\
\hline & （混合油） & 物材 & $4.8 \mathrm{~L}^{\left.i \frac{i}{2} 3\right)}$ & 205 \\
\hline 施肥 & 未実施 & & - & \\
\hline 除草剤散布 & 未実施 & & - & \\
\hline 病害虫防除 & 未実施 & & - & \\
\hline \multicolumn{5}{|l|}{ (5)収穫 } \\
\hline 伐採・収集 & 刈り払い機 & 労賃 & 18 人工 & 34,615 \\
\hline & （混合油） & 物財 & $43.2 \mathrm{~L}^{\text {注 } 3)}$ & 1,846 \\
\hline 運搬 & 未実施 & & - & $37,840^{\text {注 } 4)}$ \\
\hline (6)農地復旧 & 未実施 & & - & $55,000^{\text {注 } 4)}$ \\
\hline
\end{tabular}

注：1）委託は作業委託費, 物財は物財費を意味する。試算するときは T 区の単価を用いる。

2) 実延長は $1,739 \mathrm{~m}$ である。

3 ) 消費量 $0.6 \mathrm{~L} / 2$ 時間

4） T区の費用を代用

って隣接あるいは隣の畧の枝葉と交差し，遮光性が高ま るため欲間の除草が不要になる。しかし，伐採してしま うと植え付け直後と同様の状態になるため，準備期と同 様の作業が必要となる。その際除草作業や除草剂散布等 の回数を軽減し, 委託から自作へ転換することにより大 幅な抑制が可能と考えられる。

最終期は, 収穫後の農地復旧費用が収穫期の費用に加 わり, 非収穫期と同じくらいの費用だが, 農地復旧工程 の作業委託費が約 80\%を占めていた。

作業委託費は, 収穫期・非収穫期いずれにおいても半 分以上を占める結果となった。ただし，農地所有者自身 の生産とすれば，作業委託費の軽減だけでなく借地料の 負担もなくなるため, ヤナギ生産でこれ以上の経費が掛 かることはないと考える。

\section{$2 \mathrm{~K}$ 区における作業投入量}

T 区の生産方法に比べて K 区では作業投入量を極力 抑えることができた（表 5)。特に, 維持管理工程の省 力化が顕著であった。準備期では, トラクターによる 中耕除草を 13.5 回から 4 回, 刈り払い機による除草を 121.5 時間から 16 時間に減らし, 収穫期ではトラクター による中耕除草 2 回, 刈り払い機による除草を 16 時間 
に抑えられた。除草剂散布, 病害虫防除の作業は生育の 状況を見て不要とした点も大きい。施肥を不要とした点 については，栽培前，ほ場が家畜排せつ物堆肥の置き場 であったことから，追肥した場合過剩投入になると判断 した。

維持管理までの作業は比較的省力化できたが，収穫工 程（人工数）の省力化は達成できなかった。伐採作業に は山林用の刈り払い機を使用し，作業投入量の軽減を図 ったが,十分な作業投入量 (人工)軽減とはならなかった。 T 区で実施したチェーンソー伐採は上下運動が多く，作 業効率的にもロスが生じ，本数が多くなればなるほど疲 労蓄積, 効率性の低下を招く。刚り払い機はその点を改 善できると考えた方法であるが，今後は刈り払い機によ る伐採作業の経済的軽減の検証が必要となる。また，作 業実施者が高齢（70 歳前後）であった点も作業投入量 が多くなったと考えられる。

\section{3 慣行農業との生産費の比較}

本試験栽培における収穫期, 非収穫期の生産費の尺度 を測るため, 慣行農業（平成 24 年度産の米，小麦，大 豆, ナタネ, ソバ ; 農林水産省 $(2014 a,, 2014 b)^{13), 14)}$ の生産費注4，注5) と比較を行った（図 4)。ただし，各区 の生産費については，以下の手順で算出した。

(1)初期費用として，ほ場の整備，整地，植え付けの和 を求める。

(2)初期費用と農地復旧費用の和を 1 サイクルの 20 (年

間）で按分し，それを収穫期，非収穫期の費用に加 える。

(3)各期の加重平均を求める。

本稿における結果は，慣行農業に比べて費用が多いこ とが分かった。まず， $\mathrm{T}$ 区の平均生産費は $\mathrm{K}$ 区に比べ て約 2 倍と非常に高かった。次に省力栽培を実施した $\mathrm{K}$ 区の費用は，コメ生産（経営規模 $0.5 \sim 1.0$ ha）ょりも 低かったが，他の作物に対しては大きく上回っている。 既述の通り，K区の費用軽減は維持管理の省力化が特に 影響したが，収穫工程の費用を抑えることで更なる軽減 が可能となるだろう。ほ場の整備や植え付けの費用にも 両区で差は見られるものの，減価償却費用として按分さ れると各期 2 千円 $/ 10 \mathrm{a}$ の差にとどまり，やはり維持 管理費用，収穫費用をどれだけ軽減するかが課題といえ る。また, ヤナギは粗放栽培が可能であるが, 粗放栽培 で代表的なナタネやソバに比べても，その差は明らかで ある。

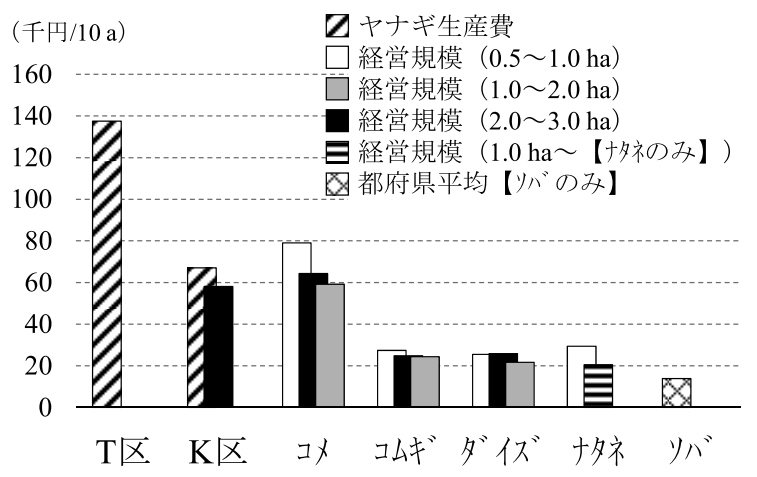

図 4 ヤナギ生産（T区，K区）と慣行農業との 生産費の比較

Fig. 4 Preference of production cost between the willow and conventional agricultures (rice, wheat, soybean, rape and buckwheat)

表 6 各ほ場での生産量（2生育期間）

Table 6 The yields in each fields during two seasons

\begin{tabular}{llrrr}
\hline \hline & & $\mathrm{T}$ 区 & $\mathrm{K}$ 区 & $\mathrm{M}^{\text {注1) }}$ \\
\hline 面積 & $(\mathrm{a})$ & 50.0 & 46.8 & 4.32 \\
植栽本数 & $($ 本 $)$ & 4,500 & 3,516 & 864 \\
植栽密度 & $($ 本 $/ 10 \mathrm{a})$ & 900 & 751 & 2,000 \\
湿重量 & $(\mathrm{kg} /$ 本 $)$ & 5.21 & 5.24 & 2.77 \\
含水率 & $(\%)$ & 43.0 & 45.0 & 42.2 \\
生存率 & $(\%)$ & 95.0 & $89.4^{\text {i亡 } 2)}$ & 83.7 \\
\hline 乾燥重量 & $($ dry-t/10a $)$ & 2.54 & 1.93 & 2.68 \\
\hline
\end{tabular}

注：1) Satoh et al., (2012) を参照

2) 不測定のため T 区と M 区の生存率の平均值を代用

\section{$\mathrm{V}$ 生産管理の作業軽減の検討}

\section{1 単位面積あたりの生産量}

$\mathrm{T}$ 区と $\mathrm{K}$ 区の比較より, 過多な除草作業は不要と考 えられる。T区と $\mathrm{K}$ 区および, 参考值として既存研 究 $\left(\right.$ Satoh et al. ${ }^{7)}$ ) のほ場（M 区：京都府舞鶴市）の 生産量（表 6）をみると， T 区の生産量は K 区よりも 0.61dry-t/10 a 多かったが, M 区とはほとんど差がみら れない。 $\mathrm{M}$ 区の生産管理は, $\mathrm{K}$ 区と同様除草作業のみ で準備期では 5 回（2009 年 5 月〜 2009 年 9 月）, 収穫 期では未実施, 病害虫防除も実施していなかった点を考 えると，生存率に多少は関係しているかもしれないが, 植栽密度の影響も考慮に入れても生産量（乾燥重量： dry-t/10 a）は除草作業を含む維持管理工程の頻度に左 右されないと考えられる。

また，北欧の事例 ${ }^{2)}(1.0 \mathrm{dry}-\mathrm{t} / 10 \mathrm{a}$ 未満）を鑑みても， 生産量は少なからず気候に影響を受けると考えられる が，本報における試験栽培ほ場の地理的距離の差では, 大きな差異は確認できなかった。ただし，1本当たりの 生産量は植栽密度に, 生存率は維持管理の頻度に関係し ていると推測する。これらについては, 統計的手法によ る検証を実施していないため明言できないが，今回の試 
験栽培から, 本ほ場のような 1 ha 未満の農地において 収穫期で約 2.0dry-t/10 a,（一期当たりに換算すると約 1.0dry-t/10 a）の生産量が見达まれる。国内における生 産量は, 概ね同量と推測できるが, 植栽密度や維持管理 の頻度については検討の余地があるだろう。

収益性の点を勘案しても改善は不可欠である。ヤナギ を燃料用チップとして利用することを前提とした場合， 今日の燃料チップ販売価格 $(12,000 \text { 円 } / \mathrm{t})^{15)}$ を鑑みると, 一期当たりの販売収益は, 約 12,000 円 $/ 10 \mathrm{a}$ 程度とな る（ただし，生産量の単位は dry-t のため若干の差はあ る)。つまり，K区の平均生産費（67,059 円／10 a）の 方が高く，このままでは販売利益は見込めない。さらな る生産費の軽減が必要である。

\section{2 作業実施における改善点}

（1）維持管理費用の改善

病害虫防除策の費用は，生産地域の気象条件や生育状 況に応じて変化する。これまでヤナギ生産過程で確認さ れている病害虫はセグロシャチホコやコウモリガの幼虫 による葉食被害とサビ病が確認されている ${ }^{3)}$ 。T 区では 未然防止として複数回の病害虫防除策を実施し被害はな かった。K区では，特に防除策は実施せずともサビ病の 発生および害虫の発生は確認されなかった。これは, 恐 らく冬場は気温が摂氏ゼロ度以下になる日が多く，一度 害虫が発生しても越冬が困難 ${ }^{16)}$ になると推察する注6)。 また，サビ病も両ほ場では確認はされなかったが，発生 した場合には拡大を防ぐためある程度の対策が必要であ る。ただし，エネルギー用ヤナギと観賞用ヤナギとでは 品質への配慮の度合がまったく異なるため, 伐採・利用 の後にほ場に残存する菌を駆除するなど 2 期を通して 1 〜 2 回程度の頻度で, 生育状況に応じた防除策を実施し ていけばよいと考える。その点, 防虫防除の際の散布作 業分の費用が生育期によって加減する可能性はある。

（2）生産管理主体による生産費の改善 本報で積算した労働費の多くは作業委託費である。ま た, 借地料も生産者所有農地であれば発生しない。ほ場 の整備工程では，ほ場の状況に応じて重機を利用せざる を得ないが，木本が植生していなければ従来のトラク夕 一や刚り払い機等による整備が可能である。整地工程も 既存のトラクターを利用すれば作業委託費の支出は抑え られる。植え付け工程についは, 現時点では人力作業に よる植栽方法しかなく, 海外の先進地域では, 整地（マ ルチングなし）と同時にトラクターの後部で人が植え付 けている事例もあるが, 本報の様な小規模農地の場合, 人力作業でも十分可能な範囲である。維持管理工程に含 まれる除草, 施肥, 除草剂散布, 病害虫防除はいずれも
慣行農業で実施される作業と同様であり，自作ならば作 業委託費分を軽減することが可能になる。ただし，スピ ードスプレイヤーは手動式背負噴霧器への代替が可能で あり，その場合は燃料費も削減できる。

以上のように, ほとんどの作業は従来の機器で代替で きる。収穫工程については, $\mathrm{K}$ 区では作業の肉体的負 担を考慮して刈り払い機を採用したが, 実質労働量は増 えてしまった。しかし，刈り払い機はほとんどの農家が 所有している機器であり新たに機器を購入する必要がな い点で, 現時点では最良な方法のひとつと考える。ただ し, 山林用刃を所有していない場合は新規購入が必要と なる。今後は, 生産管理者主体の状況による生産費の不 確実性を明示する必要があるだろう。

最後に，自作の場合の生産費を検討した。まず，農業 経営統計調査を参考に, 労働費を 1,788 円 / 時間と推定

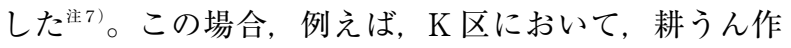
業 1 回 (8 時間) の労働費は 14,304 円/回となり, トラ クター作業の作業委託費は 1 回当たり 13,776 円 (2,944 円／10 a）の削減となる。さらに，借地料負担をなく し, IV 章 3 節の (1)〜 (3)の手順で算出すると平均生産費 は 58,081 円／10 a となった。販売収益（12,000 円／ 10 a) と比べても 46,081 円 / 10 a の久損が生じてしま い, 経済的な優位性は認できなかった。かつて Natural England が 2000 年〜 2013 年にかけてエネルギー作物助 成制度（Energy Crop Scheme） ${ }^{17)}$ を実施していたが, 当時の補助額約 $14,000 \sim 24,000$ 円 $/ 10 \mathrm{a}^{\text {注8) }}$ を勘案し ても, 改善が必要といえる。

（3）収穫費用の改善

収穫期の生産費は収穫費用に左右されるため, これを 抑制しなくてはならない。収穫費用の面では， $\mathrm{T}$ 区の収 穫方法（チェーンソー利用）の方が効率的であったが, 維持管理費用については K 区の方が低く，前述の通り 維持管理の頻度が必ずしも収穫量増につながるとは言い 切れないことから, 収穫期の生産費としては, 維持管理 は $\mathrm{K}$ 区，収穫は $\mathrm{T}$ 区の工程を取り入れることが現時点 の最良策と推察できる。ただし, 伐採方法としては, 安 全面や（上下運動による）肉体的疲労を考えると, 取り 扱いが比較的容易な刈り払い機の方が導入しやすいだろ う。収穫工程においては，収集方法も含め，作業効率を 高める方法・手順を考案する必要があると考える。

また，運搬費用を含めた検討も必要である。ヤナギは 性質が木質バイオマスと類似しているため木質バイオマ スとの混合利用が可能であり, 現時点ではバイオマスボ イラー施設での熱利用が考えられる。しかし，未利用材 利用時の問題点同様, 収穫後の運搬費用の不確実性（ど こで利用・加工されるか）が考えられ，販売価格に消費 
場所までの運搬費用を添加する方法，あるいは消費者自 身がほ場に取りに来る方法などが考えられる。後者の場 合，K区での自作による生産方法では，一期当たりの生 産費は約 39,000 円 $/ 10$ a となり, 販売時の欠損值は少 なくても約 27,000 円 $/ 10$ a まで抑えられる。

\section{VI おわりに}

本報は，短期伐可能で次世代バイオマスとして注目さ れているヤナギに着目し，遊休農地活用によるヤナギの 一連の経費を 2 つのほ場での実績を通して試算した。費 用の試算結果ならびにこれと慣行農業の生産費との比較 結果より，現段階における生産方法では，自作と作業委 託の場合で約 27,000 55,000 円 / 10 a の久損が生じ, 経済的な優位性は確認できなかった。特に収穫費用は主 な費用のひとつであり，森林バイオマス同様，伐採，収 集，運搬等の費用をどれだけ抑えるかが今後の課題とい える。ヤナギは粗放的な栽培が可能であり，食用や観賞 用等の農作物ほどの維持管理工程はさほど必要ではな く，なるべく作業委託を要しないことでさらなる費用抑 制につながる。また，既存研究を含め単位面積当たりの 生産量に大きな差は確認されず, 生産量やヤナギの生存 率が維持管理の頻度や植栽密度に関係している可能性も 示唆したが，これについては今後の検証が必要である。

最後に, 本報は, 生産工程の省力化の検証とともに生 産費, 生産管理主体ならびに収穫工程を含む生産技術の 改善点ついて言及したが，これらを踏まえたうえで遊休 農地にみられる小規模農地でのヤナギ生産導入の可能性 評価については今後の課題としたい。

\section{謝辞}

本研究は, 宮城県川崎町におけるヤナギの試験栽培について は, 三井物産環境基金 (2011年度東日本大震災復興助成)課題 $\lceil$ 早 生樹（ヤナギ）栽培による木質バイオマス生産の実証展示と挿 し木供給体制の整備」，投稿・掲載については, JSPS 科研費（研 究課題番号 26740053）の助成によるものである。そして，各 ほ場の栽培管理および収穫作業を請け負っていただいた地元の 皆様に,この場を抒借りして改めて感謝申し上げたい。

\section{注}

注 1 ) 兵庫県林業種苗共同組合（2014）より，スギとヒノキの 苗令 $2 \sim 3$ 年で品等呼称が「小」とされる樹苗の平均販売 価格とした。

注 2 ）宮城県川崎町の農業従事者への労賃支払いは，同町農業 委員会による農作業標準賃金額表をもとに行った。

注 3 ） 1 人工 $=8$ 時間 $/$ 日 / 人

注 4 ）生産費は，物材費と労働費の和とした。なお，ナ夕ネ とソバ以外はいずれも作付規模別 $0.5 \sim 1.0$ ha, $1.0 \sim 2.0$ ha, $2.0 \sim 3.0$ ha の都府県の平均生産費（10 a 当たりの生 産費）とした。ナタネは $0.5 \sim 1.0$ ha と 1.0 ha 以上の 2 分 類のみであり, ソバは規模区分がないため, 都府県の平均 生産費（同生産費）とした。調査対象経営体は作付け作物 によって異なるため, 各対象経営体については, 農林水 産省 ${ }^{13)}$. 14) の作物ごとにある「調査対象経営体の経営概況」 を参照されたい。

注 5 ）農林水産省 ${ }^{13)}$, 14) による生産費項目は大きく物財費, 労 働費に分けられている。本報のヤナギ生産費は, 物財費と 労働費（委託費用と作業労賃）の和としており，慣行農業 については，これに相当するように，物財費は種苗費，肥 料費, 農業薬剤費, 光熱動力費, その他の諸材料費の合計 とし, 労働費は直接労働費のみとした。そのため本報では, 副産物価格や資本利子・地代全額算入生産費については割 愛する。

注 6 ）有沢（1971）によるとセグロシャチホコの幼虫は 15 度 以下の温度は生育制限温度であり, 繁殖能力が低下する。

注 7 ) 農業経営統計調查（農林水産省）に抢ける「家族労働費 の算出」方法を参考とした。本報の調査期間である 2011 年 3 月〜 2013 年 12 月の間の毎月勤労統計調查 (全国調查,

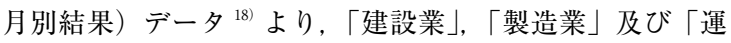
輸業，郵便業」に属する 5 ～ 29 人規模の事業所の賃金デ ー夕ならびに労働時間を抽出し, これらすべての業種の平 均労働賃金（円／時間）を算出した。ただし，抽出した賃 金データならびに労働時間はいずれも「所定内」とした。

注 8 ) 岡久 (2005) による調查值 ${ }^{19)} 920 \sim 160 £ /$ ha を参考に, 2013 年平均レート（152.69 円／£）で換算した。

\section{引用文献}

1 ）農林水産省（2014）：農林漁業の健全な発展と調査のと れた再生可能エネルギー電気発電の促進に関する法律（農 山漁村再生可能エネルギー法), 〈http://www.maff.go.jp/j/ shokusan/renewable/energy/pdf/re_ene6.pdf $\rangle, 2014$ 年 5 月 6 日.

2 ) Sara G.G., Blas M.Y. and Ioannis D. (2012): Environmental assessment of energy production based on long term commercial willow plantation in Sweden, Science oT 区 he Total Environment, 421-422, 210-219.

3 ) Beyhan Y. Amichev, Ryan D. Hangs, Nicolas Belanger, Timothy A. Volk, Vladimir Vujanovic, Jeff J. Schoenau and Ken C. J. Van Rees (2015): First-rotation Yields of 30 shortrotation willow cultivars in central Saskatchewan, Canada, Bioenergy Res. 8, 292-306.

4 ）北海道開発局（2010）：北海道におけるヤナギ栽培マニュ アル平成 22 年度版。

5 ）森林総合研究所 (2014)：北海道におけるエネルギー作物 「ヤナギ」の生産の可能性, 森林総合研究所北海道支所 植物 土壤系研究グループ, 14.

6 ）佐藤茂, 西尾麻里, 湊和也, 三井佑, 瀬戸晶子, 石澤公明 （2009）：短伐期ヤナギ林によるバイオマスエネルギー資源生 産一高生産種, 生産量, 総発熱量一, バイオマス科学会議発 表論文集 (4)，54-55.

7 ) Satoh S., Ishizawa K., Mitsui Y. and Minato K. (2012): 
Growth and above-ground biomass production of a willow clone with high productivity, Salix pet-susu clone KKD, Journal of the Japan Institute of Energy, 91, 948-953.

8 ) Rosenvist H. and Dawson M. (2005): Economics of willow growing in Northern Ireland, Biomass and Bioenergy 28, 7-14.

9 )気象庁 (2014a)：高層気象台, 〈http://www.data.jma. go.jp/obd/stats/etrn/index.php?prec_no $=40 \&$ block_no $=476$ $46 \&$ year $=\&$ month $=\&$ day $=\& v i e w=>, 2014$ 年 4 月 30 日.

10）気象庁 $(2014 \mathrm{~b})$ ：仙台管区気象台, 〈http://www.data. jma.go.jp/obd/stats/etrn/index.php?prec_no=34\&block_no $=47590 \&$ year $=\&$ month $=\&$ day $=\& v i e w=>, 2014$ 年 4 月 30 日.

11）厚生労働省 (2005): 平成 16 年林業労働者職種別賃金調查, 〈http://www.e-stat.go.jp/SG1/estat/Xlsdl.do?sinfid= $000001257600\rangle, 2014$ 年 9 月 25 日.

12）兵庫県林業種苗共同組合（2014）：平成 26 年度林業用樹苗 標準価格,〈http://www.geocities.co.jp/hyogo_naegi/ryutsu/ hyozyun_kakaku.html〉, 2014 年 12 月 22 日.
13）農林水産省 (2014a)：農業経営統計調查, 平成 24 年度産 米及び麦類の生産費,〈http://www.e-stat.go.jp/SG1/estat/ List.do?lid $=000001117795\rangle, 2014$ 年 8 月 5 日.

14）農林水産省 $(2014 b)$ : 農業経営統計調査, 平成 24 年度 産工芸農作物等の生産費, 〈http://www.e-stat.go.jp/SG1/ estat/List.do?lid=000001114487〉, 2014 年 8 月 5 日.

15）全国木材チップ工業連合会（2015）：木材チップ市況 平成 27 年 10 月, 燃料用等 (岩手), http://zmchip.com/ chipprice2710.html, 2015 年 11 月 27 日.

16）有沢浩（1971）：セグロシャチホコ幼虫の発育におよぼす 温度の影響, 日本林學北海道支部講演集 (19)，173-175.

17) Natural England (2014): Energy Crops Scheme.

18）厚生労働省（2016）: 毎月勤労統計調查, 全国調查（月別 結果 ), 2011 年 3 月 2013 年 12 月, 〈http://www.mhlw. go.jp/toukei/list/30-1a.html, 2016 年 1 月 18 日.

19）岡久慶 (2005)：イギリスの再生可能エネルギー法制, 外 国の立法 225, 43-51.

Summary: Local production for local consumption of renewable energy is focused on as a policy of regional activation in rural area while it is considered a social problem that farmlands are desolate there. This report mentioned the cost during pilot production of willow, which is called one of the neo-generation biomass, in two small-scale idle farmlands (under one hectare) aiming for the farmlands preservation. From the results, we confirmed that the production by either outsourcing or land owner in this report were into the red (about $-55,000$ to $-27,000 \mathrm{JPY} / 10$ a) and that the yield of willow was about 1.0 dry-t/10a in one season although higher planting density reduce the yield per a tree regardless of the management frequency.

キーワード (Keywords) : ヤナギ (willow), エネルギー作物 (energy coppice), 小規模遊休農地（small-scale idle farmland）, 生産 費 (production cost)

(2015年 4 月 1 日 原稿受理)

（2016年 2 月 12 日 採用決定） 